\title{
Downward shortwave radiation estimation and spatial assessment on sites over complex terrain applying integrative approach of MTCLIM-XL, interpolation, RS and GIS
}

\author{
Tariq Sardar ${ }^{1} \cdot$ Aigong $\mathbf{X u}^{1} \cdot$ Abdur Raziq ${ }^{1}$
}

Published online: 6 March 2017

(c) The Author(s) 2017. This article is published with open access at Springerlink.com

\begin{abstract}
Downward shortwave radiation (DSR) is a highly variable solar source on spatiotemporal basis and essential for energy and agriculture systems, while its calculations are helpful in the environment-related studies, climatology, and monitoring fire risk. Statistical methods developed to extrapolate values of climatic variables and radiation could fail to generate reliable findings of DSR over a complex terrain without considering local topographic factors. In the present study, we proposed an integrative approach of MTCLIM-XL extrapolation with remote sensing (RS) and geographic information system (GIS) to estimate real-time DSR and its spatial potential over surfaces of contrasting elevated sites on a mountainous terrain of Quetta (Pakistan).Based on methodological approach, remote sensing data product of high-resolution DEM (SRTM 30m) was processed to extract topographic data, and meteorological data were obtained from a base site, Subsequently, MTCLIM-XL executed the simulation to calculate the daily-based DSR $\left(\mathrm{W} / \mathrm{m}^{2}\right)$.Spatial distribution of DSR was generated by applying deterministic interpolation with complementing quantification of Hillshade analysis for spatially obstructive surfaces, and resultant spatial hotspot-based potential was assessed on basis of specified threshold level (above $250 \mathrm{~W} /$ $\mathrm{m}^{2}=2 \mathrm{~kW} \mathrm{~h} / \mathrm{m}^{2}$ ) over the specified area. We observed usable potential of DSR at target sites and its spatial distribution during the study period of 2015 to April 2016. Using EUMETSAT CMSAF data as a standard, the validation demonstrates agreeable results of low RMSE and
\end{abstract}

Aigong $\mathrm{Xu}$

xu_ag@126.com

1 School of Geomatics, Liaoning Technical University, Fuxin, Liaoning, China high correlation coefficient values for selected sites, except some sites with relatively high elevations and irregular gradients. Analysis of solar zenith angle to evaluate its inverse relation with increment in DSR values shows agreeable high inverse relation, while the negative trend for only some sites features relatively high rugged topography. In conclusion, MTCLIM-XL with RS and GIS integration manifests as a reliable approach for estimation and spatial potential assessment-based exploration of DSR over complex terrain having no ground data, while prospectively it will complement to the environment-related studies on local to mesoscale.

Keywords Downward shortwave radiation .

Environment · Complex terrain · Remote sensing .

MTCLIM-XL · GIS · Spatial distribution

$\begin{array}{ll}\text { Abbreviations } & \\ \text { MTCLIM-XL } & \text { Mountain microclimate simulator } \\ \text { RS } & \text { Remote sensing } \\ \text { GIS } & \text { Geographic information system }\end{array}$

\section{Introduction}

Shortwave radiation comprises $85 \%$ of solar radiation as incident flux and is the major solar energy source that drives many important processes related to energy and agricultural systems (Klassen and Bugbee 2004). The estimation of downward shortwave radiation (hereafter; DSR) is used in agriculture (crop modeling); in hydrology for watershed and runoff analysis, climate-related studies and for the estimation of the real-time solar energy forecast (NOAA-NESDIS ATBD July 2012). Downward shortwave radiation (hereafter; DSR) is a highly variable source on a 
spatiotemporal basis on the earth surface, so a reliable source of estimation (calculation) is a prerequisite for exploitation of its potential in any region. Specifically, in areas with the irregular mountainous terrain, the meteorological and radiometric stations are sparsely located with a lack of updated meteorological and climatic data. In many climatological and meteorological applications, accurate point-based simulation (extrapolation or interpolation) depends on pre-observed data within specific near distance of target study location (Jeffrey et al. 2001).

Statistical methods give good results in the target area and sites with regular terrain, for extrapolation and interpolation of climatic variables, from reference base sites and area (Custer et al. 1996; Thornton et al. 1997; McKeeny et al. 2006; Hamann and Wang 2005).However, the resultant calculations are unreliable and show discrepancies when the sample stations sparsely distributed over a complex terrain (Hamann and Wang, 2005). Without analyzing the local physiographic factors in area with an irregular terrain, calculations will not be helpful to produce better climatic data (Custer et al. 1996; Almeida and Landsberg 2003). Therefore, advanced and reliable methodological approach should be adopted which take into account local and physiographic factors of the target sites and area over a complex terrain and generate reliable spatiotemporal output data.

The progressive approach has been found focusing solar flux assessment studies toward climatic and irradiance estimation, and latest models and research studies have been developed on extrapolation- and interpolation-based approach. Models of spatial interpolation and extrapolation for climatic data are model of the parameter-elevation regressions on independent slopes (PRISM, Daly et al. 2008), and DAYMET (Thornton et al. 1997) which generate continuous grid base climatic data on multi-meteorological stations. However, these models required multistations for extrapolation of data. The advance extrapolation model mountain microclimate (MTCLIM) (Running et al. 1987; Hungerford et al. 1989) has developed and applied for extrapolation of meteorological and microclimatic components. Studies with MTCLIM-Applications (through its updated development) are; Glassy and Running (1994), Thornton et al. (1997, 2000), Chiesi et al. (2002), Almeida and Landsberg (2003), Hunter and Meentemeyer (2005). Grafius and Malanson (2009) evaluated MT-CLIM climate model for the estimation of snowfall at tree-line sites across the Western United States to improve modeling of alpine tree-line responses to climate change. Lo et al. (2011) evaluate the performance of the MTCLIM model in three arid sites located in southern interior British Columbia, with short data required meteorological variables, and observed better and accurate data values for the temperature of target sites.
Few studies have been found on assessment of solar radiation, specifically radiation components over complex terrain in Pakistan, including Ambreen et al. (2011), Sultan et al. (2014), and Sultan et al. (2015). However, no study has been found on the shortwave radiation estimation in the region (Pakistan) particularly complex terrain and the focus study area. However, according to the date studies (to authors knowledge), MTCLIM as well as the advanced version of MTCLIM-XL has not yet applied or evaluated for the estimation of DSR on sites located over a complex terrain with lack of ground data. In addition, MTCLIM has not included the effect of local horizons in complex terrain which obstruct the incident radiation toward surfaces due to shaded relief. Objectively, to assess the downward shortwave radiation, and its spatial variation and distribution-based potential sites, we present the study to estimate the DSR by using advance MTCLIM-XL and incorporate a Hillshade analysis for analysis of local obstruction of DSR due to irregular surfaces; integrative approach of the remote sensing and geo-information system GIS for selected sites over mountainous terrain of focused study area Quetta (Pakistan). The aim of present study is to develop the present approach that can be applicable to estimate and generate reliable data and spatial potential of the DSR for environment and climate-related studies over topographically complex sites terrains having no ground data.

\section{Materials and methods}

\subsection{Study area}

The study area, valley of Quetta city (as a base site), lies between latitude $30^{\circ} 10^{\prime} 59.77^{\prime \prime}$ North and longitude $66^{\circ} 59^{\prime} 47.22^{\prime \prime}$ East with an area of $2653 \mathrm{~km}^{2}$ (1024 sq. mi) and surrounded by hills on all sides (Wikipedia N p 2016). The selected six target sites are located within area range of $25-30 \mathrm{~km}$ of the base station at a rugged terrain of surrounding mountains with the rocky landscape. The selected study area is shown in the map (Fig. 1) with its elevation and extent within the focused region.

\subsection{The MTCLIM model}

MTCLIM model is developed on the basis of the algorithm by Bristow and Campbell 1984) that relates diurnal air temperature amplitude to atmospheric transmittance. It requires only daily maximum and minimum air temperatures and precipitation for the analysis of algorithm. Accordingly, a relationship exists between the diurnal range in near-surface air temperature and the daily total solar radiation incident on the surface (Hungerford et al. 


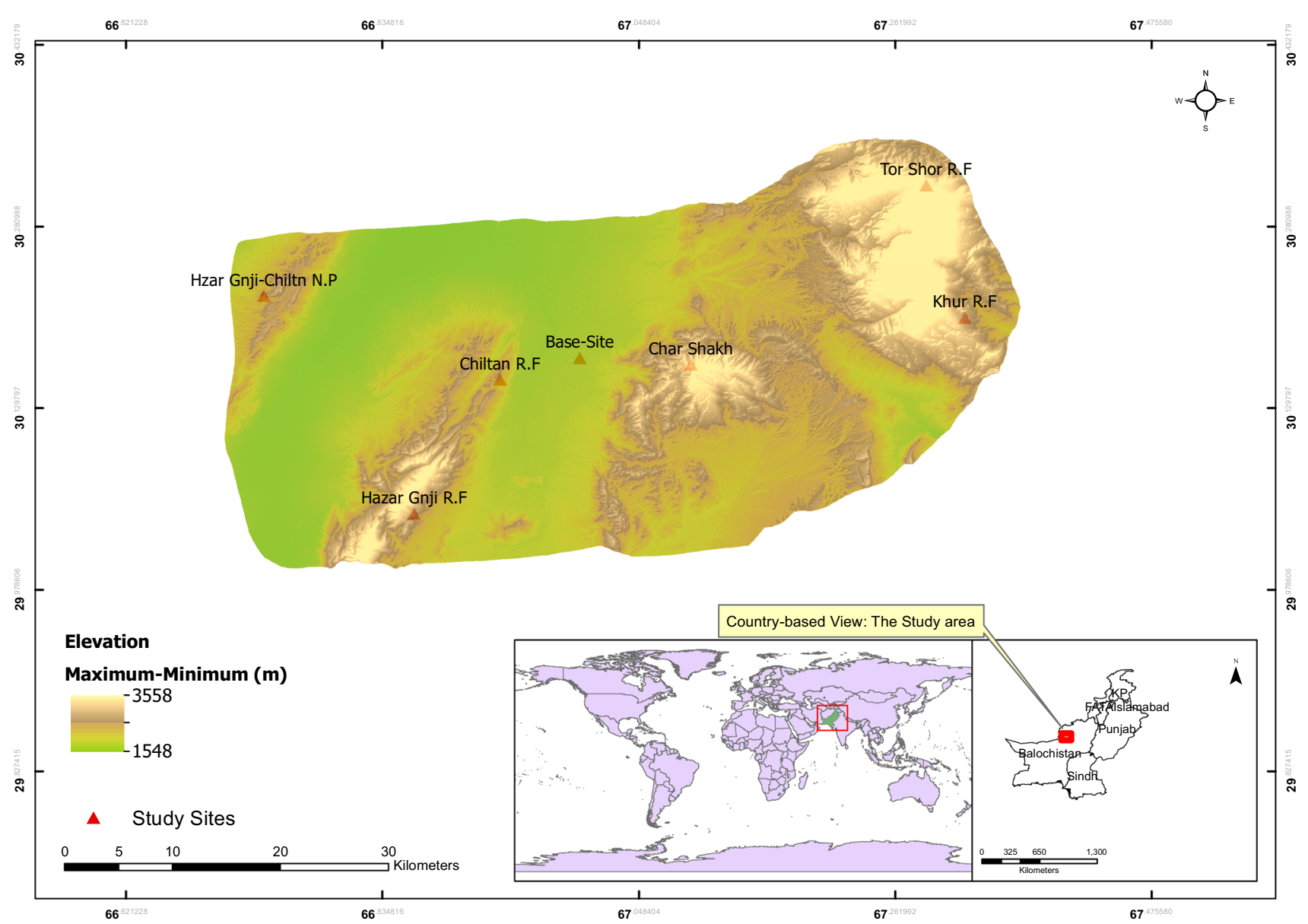

Fig. 1 Study area in context of country and the world-based location-view

1989). A potential radiation model (derived from the logic of previous mentioned models, referred/given in Hungerford et al. 1989) has been used to calculate direct and diffuse solar radiation; taking into account site differences in latitude, slope, and aspect, while truncates irradiance (direct) by East/West-horizons. Finally, calculated atmospheric transmissivity was used to produce the calculation of incoming solar radiation for the site.

According to the equation (Bristow and Campbell 1984), clear sky transmittance $(A)$ is used to calculate
Fig. 2 Flowchart of the MTCLIM model (restructured from Hungerford et al. 1989)
Site Factors: Elevation, Slope, Aspect, East/West horizon (Degree), Site latitude (identity) Base/Station Factors: Temperature (Daily Max-Min), Dewpoint (Min temp), Precipitation (Daily)

\section{Subroutines}

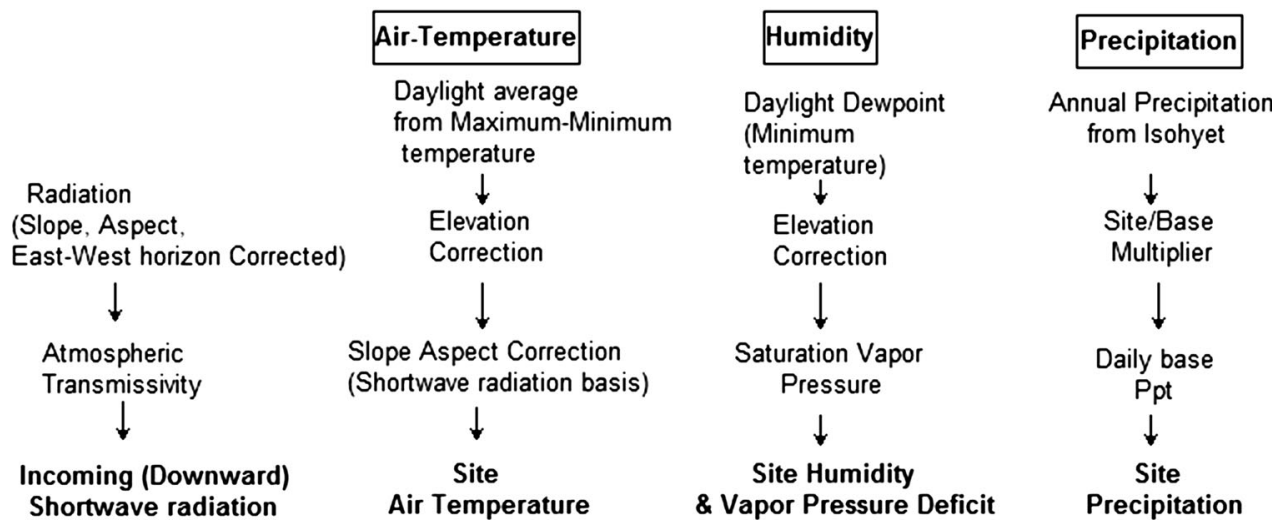


atmospheric transmittance (as a function of daily air temperature range) by:

$T_{\mathrm{t}}=A(1-\exp (-B \Delta T C))$

where $T_{\mathrm{t}}$ is the daily total atmospheric transmittance, $A$ is the maximum clear sky transmittance, $\Delta T$ is the daily range of air temperature, and $B$ and $C$ (empirical coefficients) determine how soon maximum $T_{\mathrm{t}}$ is achieved as $\Delta T$ increases ( $B$ changed with season (summer $=0.004$, winter $=0.010)$ and $C$ was held constant at 2.4).

The daily range of air temperature $(\Delta \mathrm{T})$ is calculated by the equation:

$\Delta T_{j}=T_{\text {maxj }}-\left(T_{\text {minj }}+T_{\text {minj }+1}\right)^{/ 2}$ where $\Delta T_{j}$ is the daily range of temperature for the $j$ th day, $T_{\max j}$ is the maximum temperature on the $j$ th day, $T_{\min j}$ is the minimum temperature on the $j$ th day, and $T_{\min j+1}$ is the minimum temperature on the day following the $j$ th day.

The basic equation (Hungerford et al. 1989 and references therein) calculates incoming radiation on the slope as:

$Q_{\mathrm{s}}=\mathrm{Is}_{\mathrm{s}}+D_{\mathrm{s}}$

where $Q_{\mathrm{s}}$ is the total incoming radiation (on a slope) at the earth's surface, $\mathrm{Is}_{\mathrm{s}}$ is the direct beam radiation (on a slope) at the earth's surface, and $D_{\mathrm{s}}$ is the diffuse radiation (at the surface).
Fig. 3 Physiographic features of study sites/area (a) slope and (b) aspect
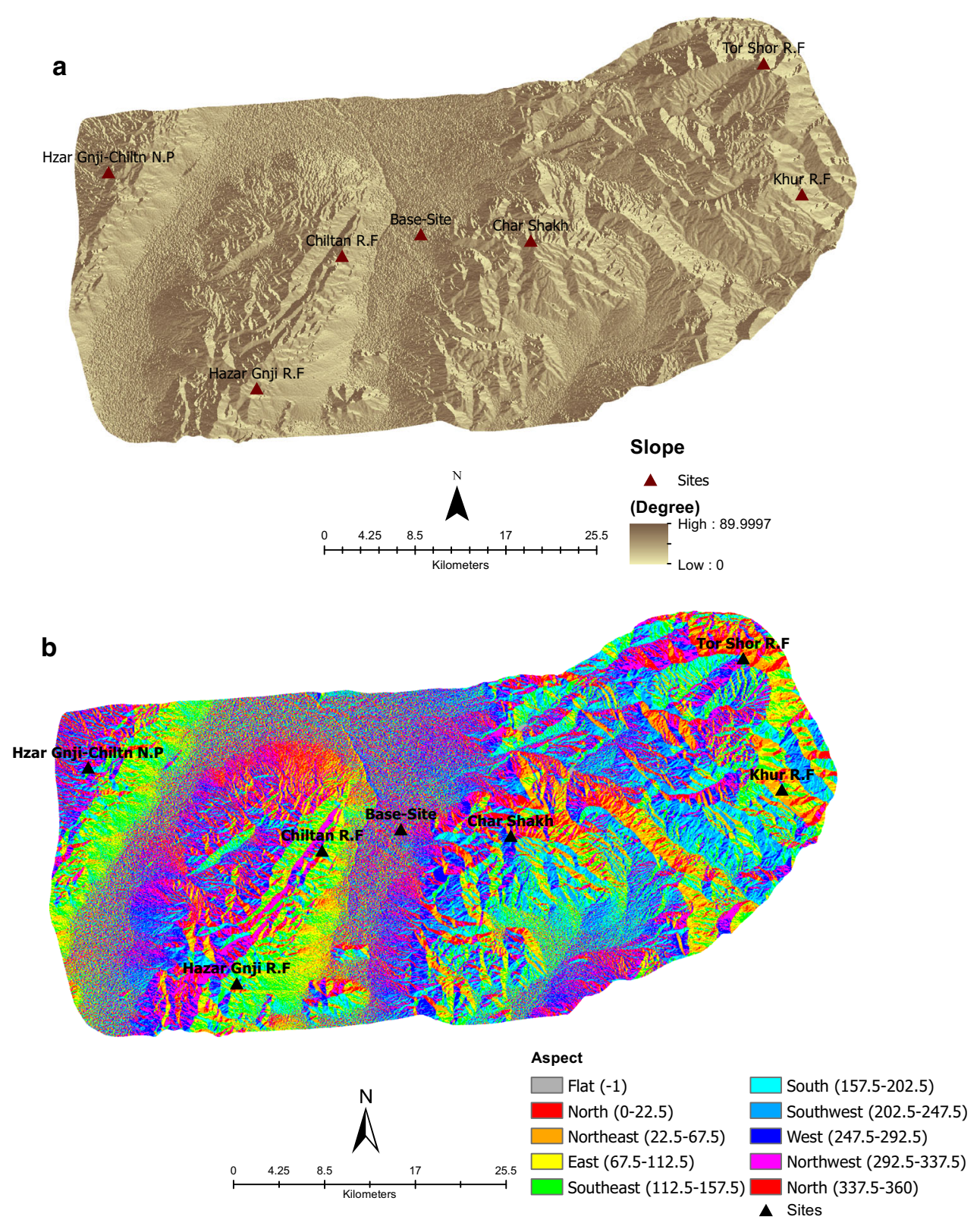
Finally, the direct beam radiation $\mathrm{Is}_{\mathrm{s}}$ at the surface is calculated as:

$\mathrm{Is}_{\mathrm{s}}=\cos \phi\left(R_{o} N^{*} T_{t}^{\mathrm{AM}}\right)$

where $R_{o}$ is the solar constant $\left(\mathrm{kW} / \mathrm{m}^{2}\right)$ above the atmosphere, with an average value for each month; $\mathrm{N}$ is the time interval for calculation in seconds; $T_{\mathrm{t}}$ is the daily total transmittance from Eq. (1), and AM (optical air mass) can be calculated by

$\mathrm{AM}=1.0 / \cos \phi+1.0 \times 10^{-7}$

where $\cos \phi$ is the cosine of the zenith angle.

The general logic of the MTCLIM was retained in MTCLIM-XL(version 4.3XL) 'MTCLIM for Excel packages' which has been developed in Visual Basic for Applications and the code is contained as modules embedded in the workbook (Jolly WM). It extrapolates useful predictions of daily meteorological (microclimatic) variables (DSR, humidity/VPD, temperature and day length) from a point of measurement 'Base station' to the selected "Sites", making vertical (elevation-related) corrections (differences in elevation, slope, and aspect) between the base station and the target site (Hungerford et al. 1989). A flowchart of the model components of MTCLIM is shown in Fig. 2.

In the present study, we used and evaluated the proposed MTCLIM-XL (version 4.3XL) for DSR $\left(\mathrm{W} / \mathrm{m}^{2}\right.$ ) calculation, while on the basis of calculated values, the spatial distribution-based variation and potential was estimated for selected sites and area. In the first step, we used MTCLIMXL simulation and for DSR calculation.

\subsubsection{Creating input files for initialization and simulation of MTCLIM-XL}

The MTCLIM-XL requires two input files for initialization and execution while the third files as 'output file'. The initialization file contains required information (topographic) that identifies the base station and output files about the site and base station. The second input of selected base station meteorological data file (worksheet) contains meteorological data of maximum and minimum temperature, precipitation $(\mathrm{cm})$ at the base site/station, the isohyet $(\mathrm{cm})$, maximum and minimum temperature lapse rate $\left({ }^{\circ} \mathrm{C} / \mathrm{km}\right)$, and observed dew-point temperature (optional, as: $T_{\min }=T_{\text {dew }}$ ).

Basic inputs for MTCLIMX-XL initialization (maximum and minimum temperature and precipitation $(\mathrm{cm})$ at base station) were obtained from international weather and climatological data forecast 'AccuWeather.Inc' (AccuWeather $^{\circledR}$ 2016) for the year 2015 till April 2016, as a real-time meteorological data of study area. 'AccuWeather $^{\circledR}$, provides weather forecasts with reliable accuracy (from hour to minutes) for any longitude/latitude on earth. The isohyet of the base station $(\mathrm{cm})$ was measured from the study year while taking into account the phenomenon of the variance in temperature relative to the altitude; temperature lapse rate of maximum 6 and minimum $5\left({ }^{\circ} \mathrm{C} / \mathrm{km}\right)$ was taken.

It has been observed that topographic features have a direct relation with and effects on the surface energy budget of a complex terrain (Dozier et al. 1981).The required physiographic information for initialization file, i.e., target sites; latitude, elevation, slope, and aspect, East and West horizon and elevation of reference site (base station) were generated using Arc GIS 10.1 (Geographic Information System) environment with the integration of remote sensing application to generate spatially reliable data. For this purpose, a high-resolution $(30 \mathrm{~m})$ digital elevation model (DEM) dataset was obtained from highresolution Shuttle Radar Topography Mission (SRTM) (Open Topography 2016) and processed in Arc GIS 10.1 environment using 'Spatial-analyst tools'. The generated layers of elevation, slope and aspect were extracted to the target points of the study layer. For focused and reliable spatial analysis of the study, terrain-processed digital elevation model/DEM-layer was clipped to study area-layer file. Finally, points (sites)-based topographic information spatial layers (maps) of slope and aspect as well as spatial elevation gradient of the study area were generated, shown in Fig. 3a, b.

Table 1 Estimated daily mean downward shortwave radiation-DSR for the year 2015 at study sites

\begin{tabular}{lllll}
\hline Site & Elevation $(\mathrm{m})$ & Latitude $\left({ }^{\circ} \mathrm{N}\right)$ & Longitude $\left({ }^{\circ} \mathrm{E}\right)$ & Daily mean SW-rad $\left(\mathrm{W} / \mathrm{m}^{2}\right)$ \\
\hline Base site & 1679 & 30.179403 & 66.99925 & 183.44 \\
Char Shakh & 3121 & 30.161358 & 67.097539 & 214.08 \\
Tor Shor reserved forest & 3181 & 30.316292 & 67.287 & 289.69 \\
Khur reserved forest & 2618 & 30.209617 & 67.32046 & 299.51 \\
Chiltan reserved forest & 2052 & 30.156624 & 66.938775 & 283.53 \\
Hazar Ganji reserved forest & 2295 & 30.041192 & 66.866783 & 262.55 \\
Hazar Ganji Chiltan national Park & 2212 & 30.223152 & 66.735978 & 297.28 \\
\hline
\end{tabular}


Table 2 Estimated daily mean downward shortwave radiation for year 2016 (till April) at study sites

\begin{tabular}{lllll}
\hline Site & Elevation $(\mathrm{m})$ & Latitude $\left({ }^{\circ} \mathrm{N}\right)$ & Longitude $\left({ }^{\circ} \mathrm{E}\right)$ & Daily mean SW-rad $\left(\mathrm{W} / \mathrm{m}^{2}\right)$ \\
\hline Base site & 1679 & 30.179403 & 66.99925 & 169.2 \\
Char Shakh & 3121 & 30.161358 & 67.097539 & 196.22 \\
Tor Shor reserved forest & 3181 & 30.316292 & 67.287 & 308.35 \\
Khur reserved forest & 2618 & 30.209617 & 67.32046 & 334.82 \\
Chiltan reserved forest & 2052 & 30.156624 & 66.938775 & 303.41 \\
Hazar Ganji reserved forest & 2295 & 30.041192 & 66.866783 & 301.15 \\
Hazar Ganji-Chiltan national park & 2212 & 30.223152 & 66.735978 & 337.34 \\
\hline
\end{tabular}

Table 3 Monthly basis downward shortwave radiation-DSR (daily mean based) for the year 2015

\begin{tabular}{|c|c|c|c|c|c|c|c|c|c|c|c|c|}
\hline Site/station & January & February & March & April & May & June & July & August & September & October & November & December \\
\hline Base Station/site & 118.04 & 159.7 & 186.13 & 215.38 & 238.93 & 217.7 & 207.22 & 219.52 & 194.74 & 164.88 & 145.79 & 132.29 \\
\hline Char Shakh & 128.03 & 177.41 & 219.1 & 261.25 & 286 & 265.61 & 260.44 & 263.94 & 227.69 & 185.2 & 154.77 & 137.63 \\
\hline $\begin{array}{l}\text { Tor Shor } \\
\text { reserved forest }\end{array}$ & 361.29 & 302.16 & 320.34 & 329.37 & 309.55 & 248.78 & 239.48 & 288.12 & 280.02 & 263.26 & 266.38 & 267.63 \\
\hline $\begin{array}{l}\text { Khur reserved } \\
\text { forest }\end{array}$ & 456.56 & 334.33 & 325.07 & 308.07 & 274.54 & 226.8 & 220.25 & 267.64 & 275.04 & 277.11 & 306.04 & 323.41 \\
\hline $\begin{array}{l}\text { Chiltan reserved } \\
\text { forest }\end{array}$ & 361.54 & 297.6 & 314.51 & 322.88 & 301.45 & 239.51 & 229.79 & 280.43 & 272.81 & 256.18 & 261.79 & 263.99 \\
\hline $\begin{array}{l}\text { Hazar Ganji } \\
\text { reserved forest }\end{array}$ & 421.18 & 306.7 & 306.28 & 282.27 & 244.17 & 199.84 & 192.71 & 235.49 & 241.53 & 237.32 & 243.89 & 240.76 \\
\hline $\begin{array}{l}\text { Hazar Ganji- } \\
\text { Chiltan } \\
\text { national park }\end{array}$ & 480.89 & 338.54 & 319.47 & 293.85 & 257.3 & 216.48 & 210.75 & 255.86 & 268.06 & 276.17 & 313.96 & 336.93 \\
\hline
\end{tabular}

Table 4 Monthly bases DSR (daily mean based) for Year 2016 (till month of April)

\begin{tabular}{lllll}
\hline Site/station & January & February & March & April \\
\hline Base station/site & 124.05 & 156.05 & 183.79 & 213.5 \\
Char Shakh & 141.01 & 177.04 & 212.5 & 254.98 \\
Tor Shor reserved forest & 347.73 & 311.44 & 278.56 & 295.46 \\
Khur reserved forest & 434.37 & 347.82 & 278.26 & 277.84 \\
Chiltan reserved forest & 346.78 & 308.32 & 270.53 & 287.85 \\
Hazar Ganji reserved forest & 387.37 & 324.41 & 246.44 & 246.1 \\
Hazar Ganji Chiltan national park & 455.89 & 353.47 & 272.31 & 266.42 \\
\hline
\end{tabular}

\subsubsection{Executing the MTCLIM-XL-simulation}

The initialization input files (worksheets) with required ancillary and physiographical extracted data were created with meteorological observations for the present study years, 2015 and 2016 (till April), in separate files for MTCLIM-XL-simulation. After the MTCLIM-XL separate simulations, the obtained output files were obtained in a series of continuous data as daily DSR $\left(\mathrm{Srad} \mathrm{W} / \mathrm{m}^{2}\right)$. The simulations of MTCLIM-XL were sorted and run separately for all the study sites consecutively. The present MTCLIM-XL model extension '.mtc43' is added internally to the output file with calculated output values of DSR $\left(\mathrm{W} / \mathrm{m}^{2}\right)$, day length (s),vapor pressure deficit (VPD-Pascal) and temperature $\left({ }^{\circ} \mathrm{C}\right)$.

\subsection{Spatial variation and distribution of the estimated DSR with Hillshade analysis}

Geostatistical and deterministic interpolation methods have been evaluated for the irregular and predominantly arid terrain by Ahmed et al. (2014). They observed that geostatistical methods, disjunctive and universal cokriging, while deterministic methods, inverse distance weighting 


4Fig. 4 a-l(1) Interpolated monthly mean-based downward shortwave radiation (DSR) spatial distribution and variations and $\mathbf{a}-\mathbf{-}(\mathbf{2})$ after applying the Hillshade analysis(shaded relief). a January, b February, c March, d April, e May, f June, g July, h August, i September, j October, k November, I December

(IDW) and radius base function, are the best interpolators for mapping air temperature and precipitation. Focusing the present study complex topography and initial assessment of interpolation methods, we followed the inverse distance weighting (IDW) interpolation from deterministic methods for determination of spatial distribution of DSR on study sites and area. For this purpose, in Arc GIS 10.1 environment, from the Arc-tool box, the geostatistical analyst tools were used to obtain the spatially interpolated surface (cell based) of DSR at all un-sampled sites. The estimated DSR data (from MTCLIM-XL) of sites were sorted to a daily mean (monthly basis). Similarly, estimated results were averaged to get the mean annual values (daily mean) of DSR for each study site interpolated to obtain a spatial layer.

In order to take into account the influence of complex topography on the DSR spatial balance, we present the spatial (cell basis) quantification of the Hillshade analysis (shaded relief with local horizon). To determine the topography and the horizon of each pixelated point (cell), Hillshade (3D Analyst) in ArcGIS 10.1-environment was used to generate a shaded relief from the DSR-interpolated surface raster by considering the illumination source angles and shadows by consideration of local horizon-effects at each cell.

\section{Results and discussion}

\subsection{Extrapolated downward shortwave radiation}

The calculated DSR values over study sites, estimated on the daily mean basis for the study year 2015 and 2016 (up to April), are given in Tables 1, 2 which indicated that Khur reserved forest, Hazar Ganji-Chiltan national park, Tor Shor, Chiltan, and Hazar Ganji reserved forests, respectively, receive a high values of DSR during the study year 2015. Relatively minimum-to-moderate level of radiation potential was observed for the base site and Char Shakh, respectively. For the year 2016 (till April), a similar trend of radiation over sites on daily mean base was obtained from calculation. Relatively high radiation values were obtained at Hazar Ganji-Chiltan national park, Khur, Tor Shor, Chiltan, and Hazar Ganji reserved forests, respectively, given in Table 2 . In addition, the amount of DSR received at base site and Char Shakh is low to slightly high moderate level, respectively. However, the slight increment in the DSR values is agreeable as the calculation data was limited to possible obtained time for the present study, i.e., till April 2016.

Detectable variations were observed in inter-monthly DSR study years 2015-April 2016 shown in Tables 3 and 4, respectively. DSR values over Hazar Ganji-Chiltan national park, Khur reserved and Hazar Ganji reserved forests sites were the highest with maximum variations $\left(480 \mathrm{~W} / \mathrm{m}^{2}\right.$; highest to minimum; $\left.300 \mathrm{~W} / \mathrm{m}^{2}\right)$ during the initial months of the year, from January to May, shown in Table 3. However, comparatively low radiation values were obtained during next months till the end of a year. Accordingly, the observed peculiar behavior of fluctuations in radiation values can be directly or indirectly related to high elevation and irregular terrain with no specified and plain west-east running (Yang et al. 2008). Relatively low DSR values were obtained, as compared to the other sites, over the base site and Char Shakh. Accordingly, estimated values were lowest in months of January to March and gradually rise from April to September, while becoming low again from September to December, respectively. A similar trend of variations of DSR was observed for the year 2016 (until April), as given in Table 4.

\subsection{DSR spatial distribution-based variation and potential distribution (spatial hotspots)}

After the spatial quantification of Hillshade analysis of study area, interpolated DSR spatial variations and distribution over the sites and area were presented as: (a) spatial distribution and variations of DSR based on Hillshade analysis (shaded relief) and (b) assessment of potential (spatial hotspots)-based DSR spatial distribution.

\subsubsection{Spatial distribution and variations of DSR based on Hillshade analysis}

The interpolated maps for monthly averaged (daily mean base) generated on basis of spatial distribution of DSR over the sites and area are presented in Fig. 4a-1(1), while after applying the quantification of the Hillshade analysis, spatial distribution of DSR (shaded relief with local horizon) is presented sequentially in Fig. 4a-1(2).For interpolated data values (DSR), spatial variance of DSR was taken on the basis of minimum-to-high (maximum) values radiation $\left(\mathrm{W} / \mathrm{m}^{2}\right)$, while Hillshade to depict spatial variance-based obstructed surface (shadowed cells) to the maximum sun view at site and area (cells) is assigned an integer value range of $0-255$.

Four study sites with high elevation gradient Hazar Ganji-Chiltan national park, Hazar Ganji reserved forest, Chiltan reserved forest, and Khur reserved forest receives 

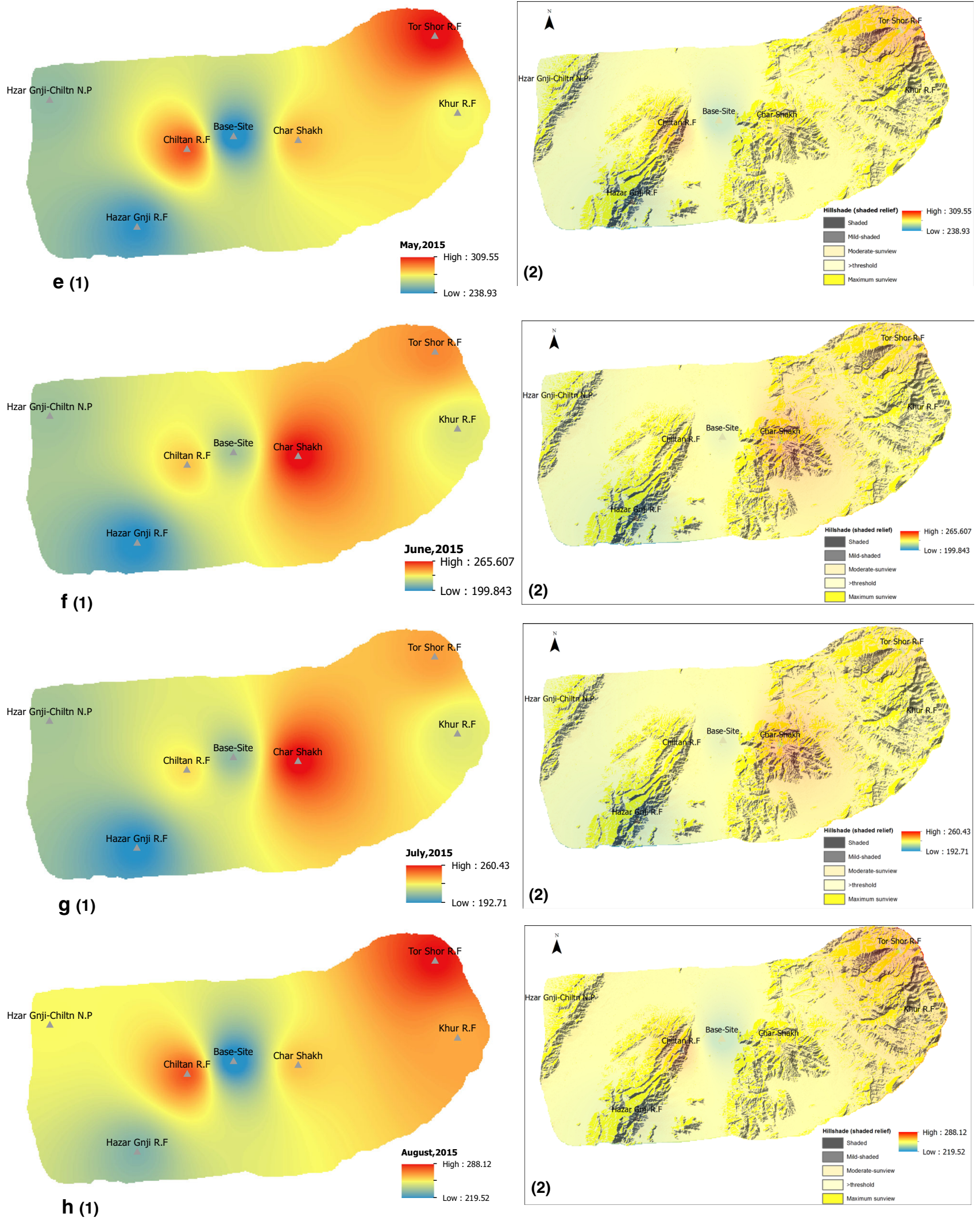

Fig. 4 continued 


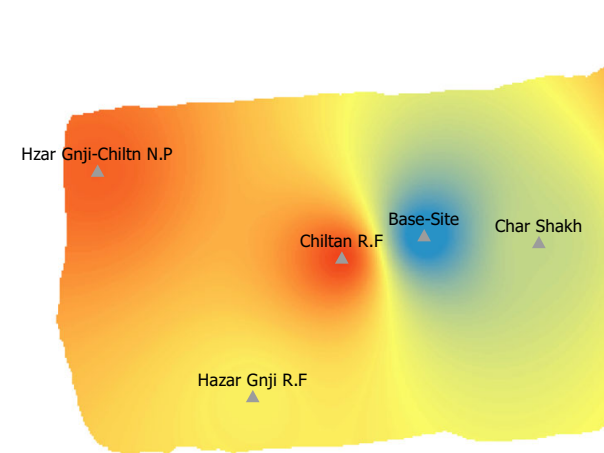

i (1)
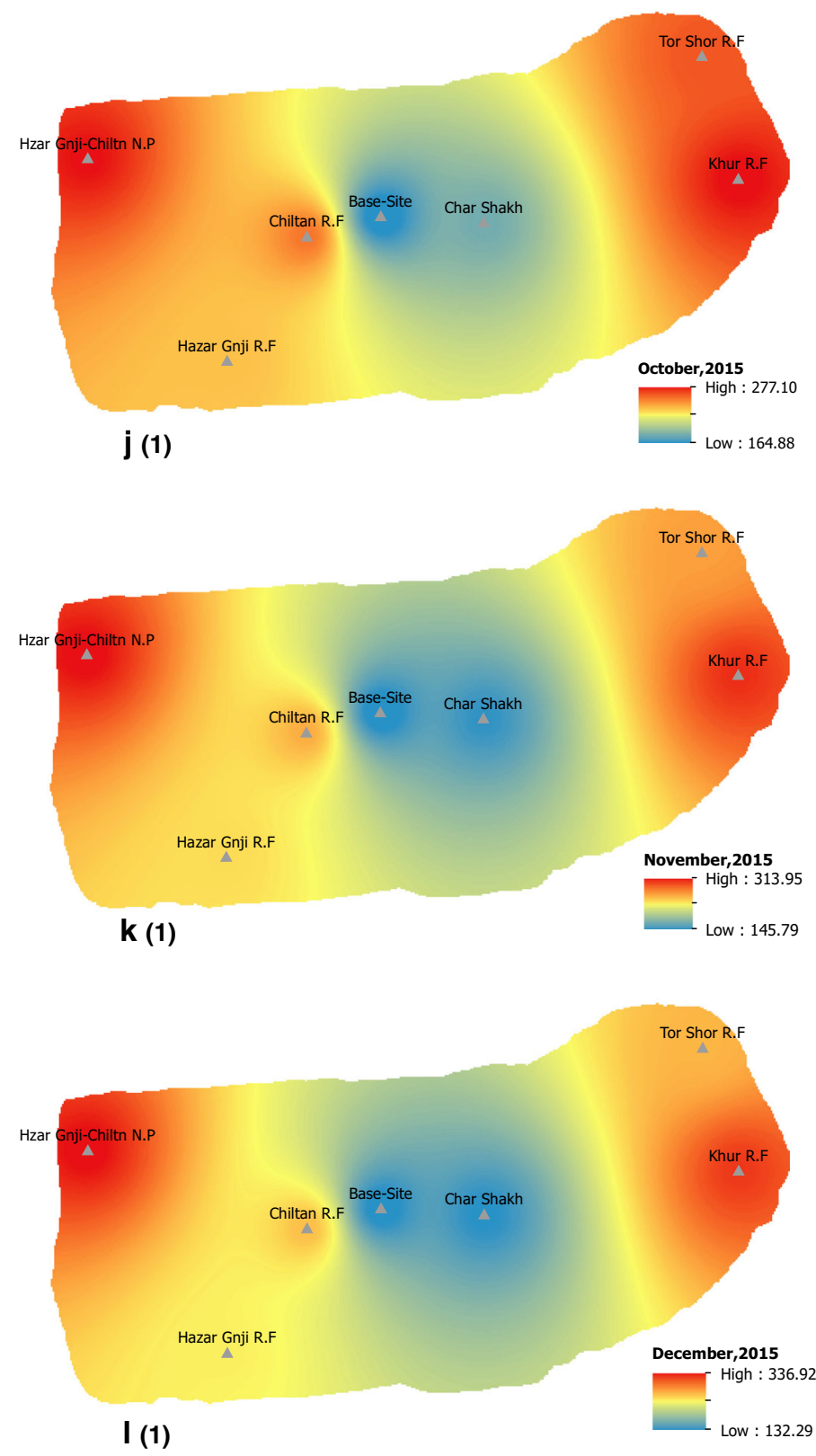
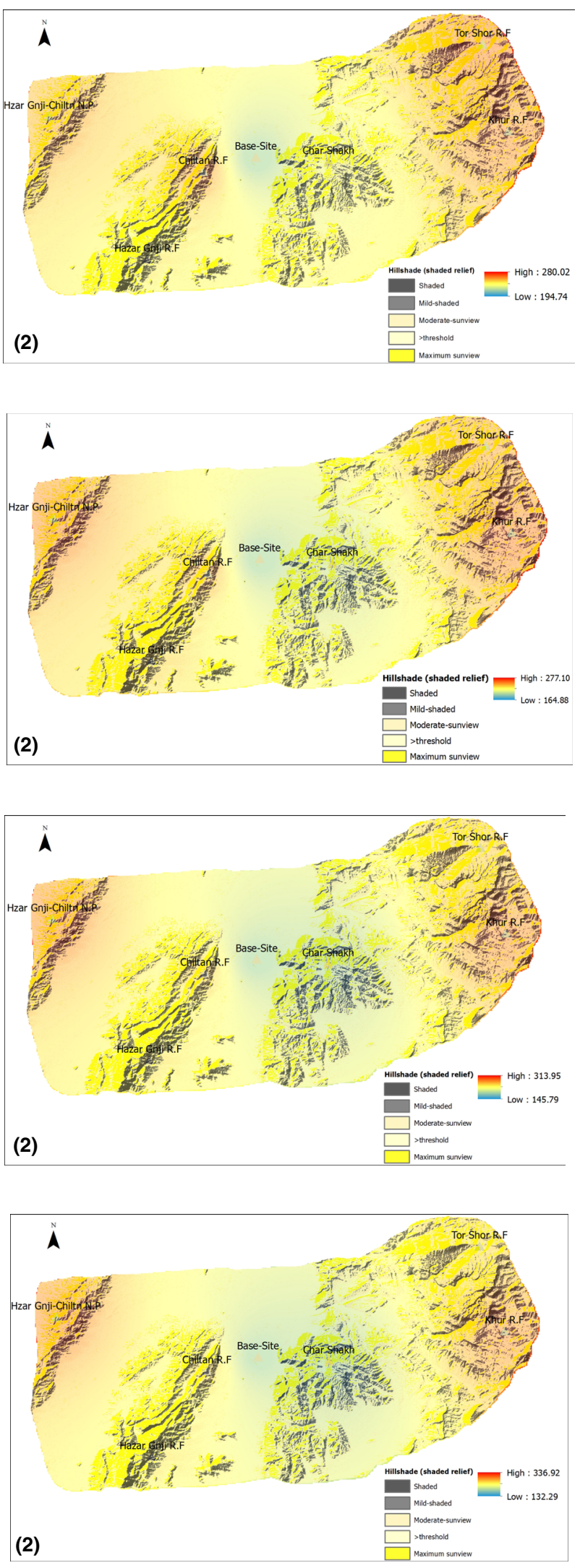

Fig. 4 continued 
Fig. 5 Potential of DSR on basis of spatial distribution in proximity of the study sites, year 2015

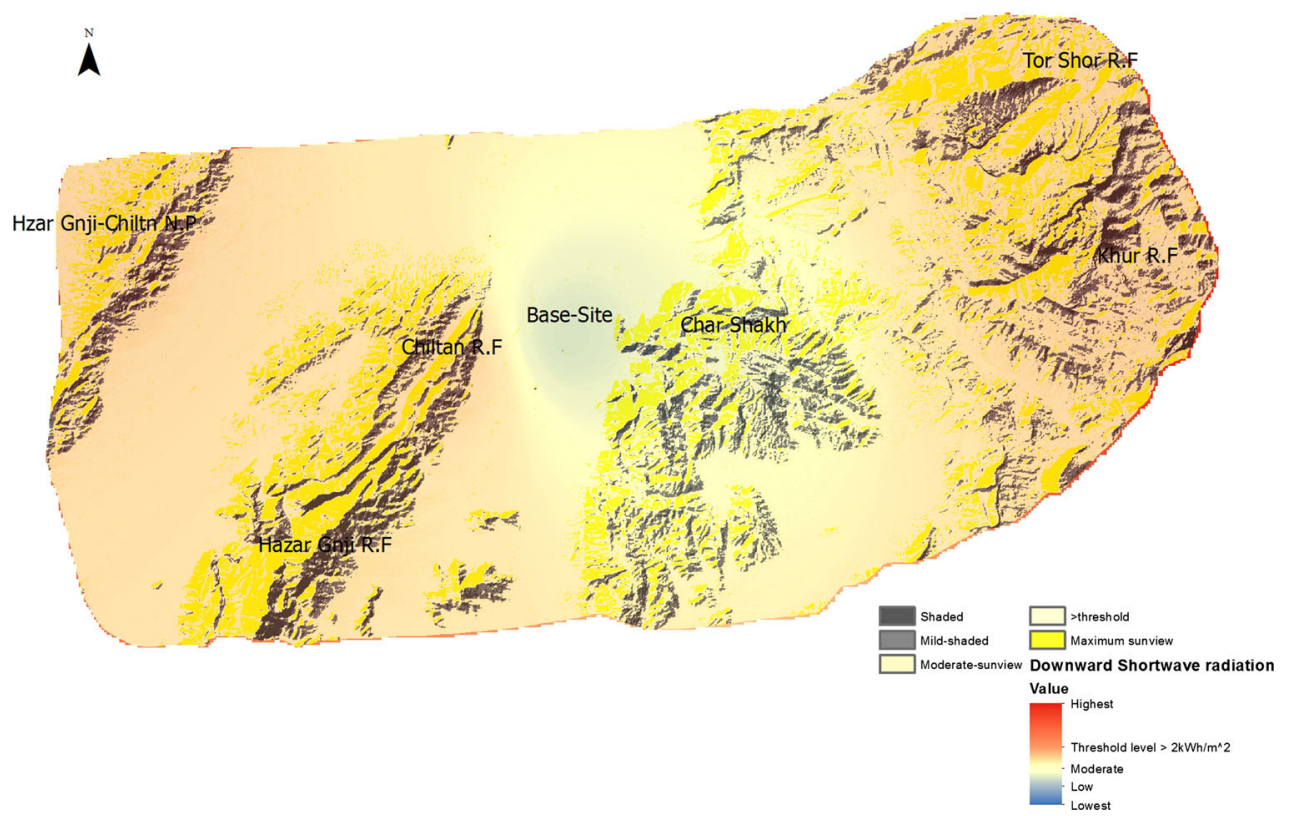

Accordingly, the interpolated estimated radiation $\left(\mathrm{W} / \mathrm{m}^{2}\right)$ values were converted into a unit of kilowatt hour per meter square area $\left(\mathrm{kW} \mathrm{h} / \mathrm{m}^{2} /\right.$ day) with following conversion formula;

$\begin{aligned} E(\mathrm{kWh}) & =P(\mathrm{~W}) \times \frac{t(\mathrm{hr})}{1000} \text { as } E=\mathrm{kW} \cdot \frac{\mathrm{h}}{\mathrm{m}^{2}} \mathrm{OR}, E \\ & =\mathrm{kWh} / \mathrm{m}^{2} / \text { day }\end{aligned}$

Here, ' $E$ ' is the energy potential from the retrieved $\mathrm{kW}$ (kilowatt) insolation (solar flux; DSR) over sites and specified area ' $\mathrm{m}^{2}$ ', and time ' $\mathrm{h}$ ' in hours/day, on available maximum daily mean $8 \mathrm{~h}$ (taken as maximum active-average sun-hours). Taking into account the quantification of the Hillshade analysis (shaded relief with local horizon) to assess the potential of DSR spatial distribution, spatial hotspots-based map was generated, shown in Fig. 5. The obtained final DSR potential on daily mean basis was: lowest $1.46-1.64 \mathrm{kWh} / \mathrm{m}^{2}$, low $1.64-1.8 \mathrm{~kW} \mathrm{~h} / \mathrm{m}^{2}$, moderate $1.8-2 \mathrm{~kW} \mathrm{~h} / \mathrm{m}^{2}$, and a threshold level of $2 \mathrm{~kW} \mathrm{~h} / \mathrm{m}^{2}$, respectively, up to the maximum values of interpolated radiation.

The potential of DSR over Hazar Ganji-Chiltan national park, Tor Shor, Hazar Ganji, and Chiltan reserved forests sites and there was above the threshold level $(2 \mathrm{~kW} \mathrm{~h} /$ $\mathrm{m}^{2} /$ day), with 'maximum sun view' surfaces, is shown in Fig. 5. However, base site, Char Shakh and Khur reserved forest sites receive the low-to-moderate level of radiation with moderately shaded relief on Base site, above the threshold level to maximum sun view on Char Shakh. It is evident that Hazar Ganji-Chiltan national park, Tor Shor, Hazar Ganji, and Chiltan reserved forest and there adjacent surfaces show suitability as DSR hotspot sites. 
Fig. 6 Scatterplots of the monthly mean-based downward shortwave radiation (DSR) from MTCLIM-XL at study sites versus solar zenith angle (SZAmid of every month)
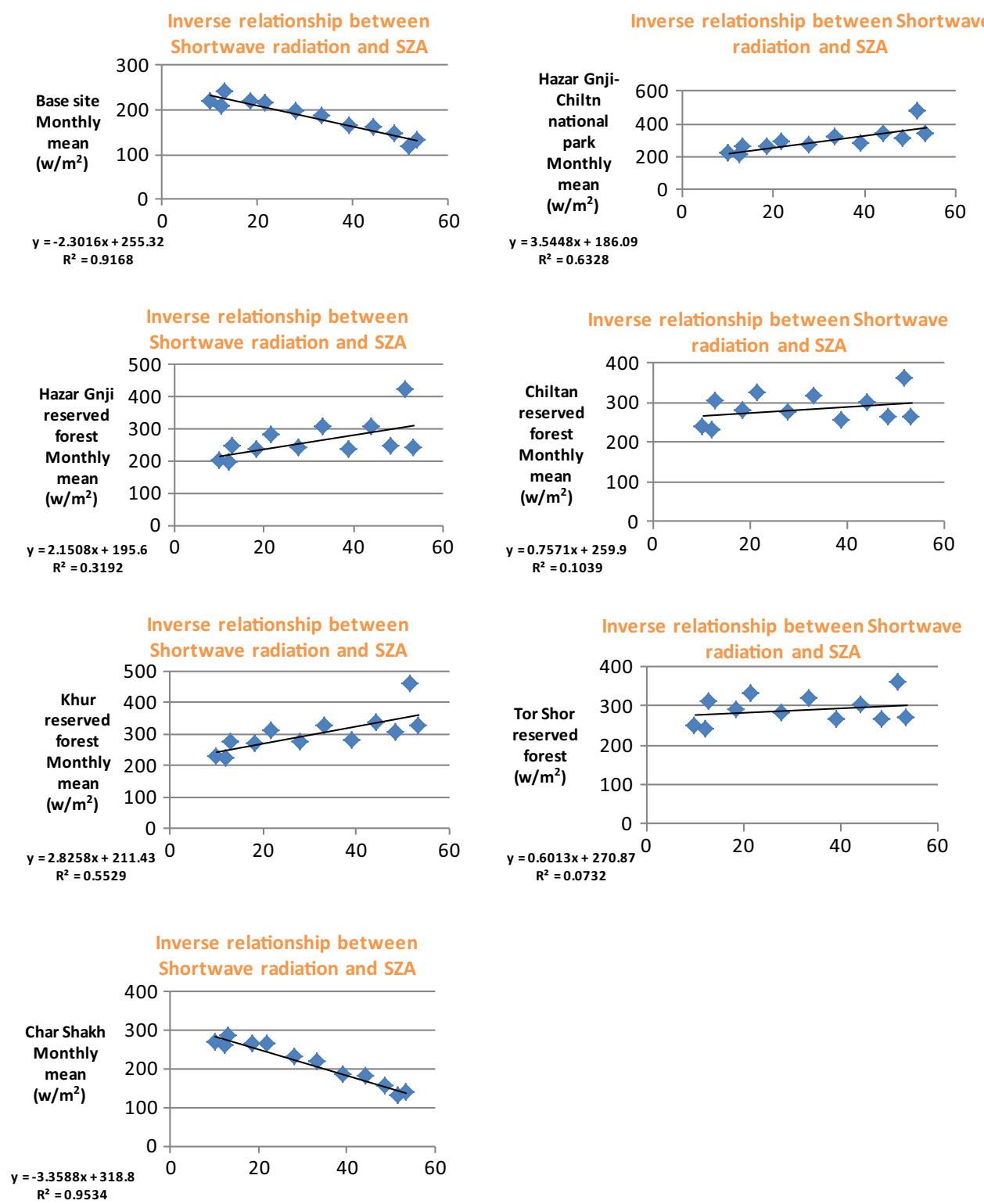

\subsection{Calculated DSR data values analysis and validation}

\subsubsection{Analysis of the DSR/SZA-correlation}

The solar radiation toward earth surface decreases with rising in solar zenith angle (SZA) as consequently the sunlight beam (heat energy) toward earth diverges from focused direction and specific location into a wide sphere $(\mathrm{Yu})$. Therefore, it can be considered as reliable evaluation approach to calculating the inverse relation between downward radiation and SZA. The SZA data calculation product, solar position calculator, was obtained from National Oceanic and Atmospheric Administration (NOAA); Earth System Research Laboratory (ESRL NOAA). Available in Microsoft Excel (Open Office format), it calculates solar data for a day or a year on any specified site with internal equations from astronomical algorithms by Jean Meeus (ESRL/NOAA). Evaluation of inverse correlation between calculated SZA and DSR was determined on the basis of calculated data values of the study year 2015 database of DSR calculation for the present study. Solar zenith angles were calculated for the target sites on the basis of a mid-monthly day (standard) for all months of year mean DSR $\left(\mathrm{W} / \mathrm{m}^{2}\right)$ values. The evaluated inverse correlation between SZA and DSR is given in the scatterplots $\left(R^{2}\right.$, ranging from 0 to 1$)$ in Fig. 6. On inverse correlation, SZA (calculated up to $60^{\circ}$ as highest value) at ' $X$-axis' as a base against estimated values of radiation, a high inverse relation between SZA and two sites; Char Shakh and base site was found, shown in Fig. 6 . Negative trend (correlation coefficients) was observed at 



Fig. 7 EverVIEW Data viewer-graphical display of shortwave radiation (EU METSAT CMSAF) over study area and region-based spatial overlay $(\mathbf{a}, \mathbf{b})$ tabular grid view; highlighted cells with the radiation data

Table 5 Root-mean-square errors (RMSE) and correlation coefficient between observed and CMSAF (satellite-products) downward shortwave radiation $\left(\mathrm{W} / \mathrm{m}^{2}\right)$ for study sites, the year 2015

\begin{tabular}{|c|c|c|c|c|c|c|c|c|c|c|c|c|}
\hline \multicolumn{13}{|c|}{ Validation/comparison with the EU METSAT-CMSAF reference data; (year 2015) } \\
\hline Site & January & February & March & April & May & June & July & August & September & October & November & December \\
\hline & \multicolumn{12}{|c|}{ RMSE (monthly mean basis) } \\
\hline Base site & 3 & 2.89 & 3.19 & 4.08 & 3.99 & 4.46 & 3.93 & 3.94 & 4.13 & 3.44 & 3.04 & 2.07 \\
\hline Char Shakh & 2.77 & 2.74 & 3.5 & 3.34 & 3.46 & 3.29 & 3.19 & 2.85 & 3.24 & 2.9 & 3.06 & 1.94 \\
\hline $\begin{array}{l}\text { Tor Shor reserved } \\
\text { forest }\end{array}$ & 6.13 & 5.01 & 5.15 & 3.75 & 3.47 & 3.6 & 3.3 & 2.41 & 2.21 & 3.52 & 4.64 & 4.48 \\
\hline Khur reserved forest & 7.4 & 5.56 & 5.24 & 3.62 & 3.64 & 4.04 & 3.52 & 2.81 & 2.33 & 3.91 & 5.32 & 5.43 \\
\hline Chiltan reserved forest & 6.1 & 4.82 & 4.75 & 3.47 & 3.2 & 4.04 & 3.61 & 2.5 & 2.32 & 3.37 & 4.52 & 4.42 \\
\hline $\begin{array}{l}\text { Hazar Ganji reserved } \\
\text { forest }\end{array}$ & 6.95 & 4.99 & 4.63 & 3.42 & 3.95 & 4.79 & 4.21 & 3.59 & 3.15 & 3.52 & 4.21 & 4.13 \\
\hline \multirow{2}{*}{$\begin{array}{l}\text { Hazar Ganji Chiltan } \\
\text { national park }\end{array}$} & 7.66 & 5.55 & 4.85 & 3.38 & 3.72 & 4.47 & 3.9 & 3.09 & 2.46 & 3.86 & 5.42 & 5.63 \\
\hline & \multicolumn{12}{|c|}{ Correlation coefficient (monthly mean basis) } \\
\hline Base site & 0.23 & 0.06 & 0.31 & 0.57 & 0.20 & 0.17 & 0.34 & 0.18 & 0.77 & 0.37 & 0.03 & -0.27 \\
\hline Char Shakh & 0.18 & 0.01 & 0.27 & 0.64 & 0.16 & 0.14 & 0.62 & 0.21 & 0.60 & 0.53 & 0.09 & -0.20 \\
\hline $\begin{array}{l}\text { Tor Shor reserved } \\
\text { forest }\end{array}$ & -0.23 & 0.23 & 0.16 & -0.35 & -0.26 & 0.30 & 0.48 & 0.11 & 0.31 & 0.26 & 0.39 & 0.36 \\
\hline Khur reserved forest & -0.23 & 0.18 & -0.12 & -0.57 & -0.25 & 0.29 & 0.46 & 0.06 & 0.19 & 0.18 & 0.32 & 0.35 \\
\hline Chiltan reserved forest & -0.22 & 0.21 & 0.11 & -0.34 & -0.29 & 0.19 & 0.29 & 0.18 & 0.47 & 0.18 & 0.29 & 0.27 \\
\hline $\begin{array}{l}\text { Hazar Ganji reserved } \\
\text { forest }\end{array}$ & -0.21 & 0.22 & -0.25 & -0.53 & -0.27 & 0.19 & 0.27 & 0.17 & 0.33 & 0.15 & 0.28 & 0.28 \\
\hline $\begin{array}{l}\text { Hazar Ganji Chiltan } \\
\text { national park }\end{array}$ & -0.23 & 0.06 & -0.40 & -0.54 & -0.2 & 0.19 & 0.25 & 0.16 & 0.29 & 0.08 & 0.23 & 0.26 \\
\hline
\end{tabular}

the three sites; Hazar Ganji-Chiltan national park, Hazar Ganji reserved forest, and Khur reserved forest. These sites indicated variance with gradual increment in SZA. In contrary to the inverse correlation of SZA with radiation, this contrasting relation is expected at irregular locations over a complex terrain. Additionally, the contrast in a normal trend of inverse behavior is due to fluctuation of radiation irrespective of correlativeness with local SZA. 


\subsubsection{Validation on spatial basis}

MTCLIM-XL calculations of the daily mean DSR (W/m²) were compared with the data obtained from EUMETSAT's Satellite Application Facility on Climate Monitoring (CM SAF) (Schulz et al. 2008) as a Daily mean incoming (downward) shortwave radiation $\left(\mathrm{W} / \mathrm{m}^{2}\right)$; SIS from Meteosat second generation. The obtained data was in NetCDF-file format and grouped under MSG-Operational products with coverage of full disk (includes Europe, Africa, Atlantic Ocean), a temporal resolution of daily basis (mean) and spatial resolution of Sinusoidal projection $\left(15 \times 15 \mathrm{~km}^{2}\right)$. The EverVIEW-Data viewer application software (Conzelmann and Romañach 2010) was used for the extraction and visualization of radiation data values (attributes) from obtained NetCDF-files. Thus, a spatiotemporal data set was generated on the daily downward (incoming) shortwave radiation for study years 2015 and 2016 (till April) (Fig. 7).

The report on daily and monthly averaged surface radiation data from the Meteosat second generation (MSG) shows the better validity of MSG data on basis of validation of shortwave radiation (Incoming/Downward) against surface measurements from the Baseline Surface Radiation Network (BSRN) which provides quality-controlled data at more than 40 stations worldwide. Accordingly, the determined bias $\left(1.6 \mathrm{~W} / \mathrm{m}^{2}\right)$ and absolute bias $\left(14.8 \mathrm{~W} / \mathrm{m}^{2}\right)$ of the data set compared to the BSRN reference data were below the optimal accuracy $\left(20 \mathrm{~W} / \mathrm{m}^{2}\right)$ as specified in the product requirements document (PRD), showing the robustness of the CMSAF data set, used for the evaluation and validation of the present study findings. Additionally, target accuracy $\left(25 \mathrm{~W} / \mathrm{m}^{2}\right)$ was achieved for all the BSRN stations which shows the reliability of the daily mean CM SAF MSG SIS dataset for ground data analysis (Trentmann and Müller 2013). A study by Juanma et al. (2006) based on the comparative analysis of surface incoming shortwave radiation (SIS) monthly average daily values $(15 \mathrm{~km}$ resolution) with the daily global radiation data from the 31 'Spanish State Meteorological Agency' (AEMET) radiometric ground station network found a better agreement between radiations values from both data sources with no systematic underestimation or overestimation, except agreeable discrepancies of $\pm 5 \%$.

The comparative analysis and evaluation were carried out on a daily mean daily mean (monthly averaged) of the study year 2015 and 2016 (till April), respectively. RMSE is considered to be best for the analysis and evaluation of differences between known and estimated values of data (Ahmed et al. 2014). Low RMSE values were observed, compared to other study sites, for the base site and Char Shakh in whole study year 2015, given in Table 5. However, for the months, April to September, slightly high RMSE values were observed for the base site as compared to the Char Shakh site, given in Table 6. At four sites, Hazar Ganji-Chiltan national park, Tor Shor, Khur, and Hazar Ganji reserved forests high values of RMSE were obtained for the initial months, January to April, while for these mentioned sites, relatively low values of RMSE were found for the months of April to October.

Variations in RMSE values are expectable and not uncommon with a random trend in estimated values of
Table 6 Root-mean-square errors (RMSE) and correlation coefficient between observed and CMSAF (satellite-products) downward shortwave radiation $\left(\mathrm{W} / \mathrm{m}^{2}\right)$ for study sites, the year 2016

\begin{tabular}{|c|c|c|c|c|}
\hline \multicolumn{5}{|c|}{ Validation/comparison with the CMSAF reference data; (year 2016) } \\
\hline Site & January & February & March & April \\
\hline \multicolumn{5}{|c|}{ RMSE (monthly mean basis) } \\
\hline Base site & 2.86 & 3.34 & 3.4 & 4.02 \\
\hline Char Shakh & 2.65 & 2.72 & 3.37 & 3.42 \\
\hline Tor Shor reserved forest & 5.99 & 4.53 & 4.45 & 3.6 \\
\hline Khur reserved forest & 7.17 & 5.25 & 4.46 & 3.56 \\
\hline Chiltan reserved forest & 5.84 & 4.43 & 4.12 & 3.41 \\
\hline Hazar Ganji reserved forest & 6.45 & 4.86 & 3.83 & 3.68 \\
\hline Hazar Ganji Chiltan national park & 7.33 & 5.33 & 4.14 & 3.51 \\
\hline \multicolumn{5}{|c|}{ Correlation coefficient (monthly mean basis) } \\
\hline Base site & 0.25 & 0.05 & 0.33 & 0.42 \\
\hline Char Shakh & 0.13 & 0.24 & 0.50 & 0.51 \\
\hline Tor Shor reserved forest & -0.11 & 0.17 & 0.30 & 0.29 \\
\hline Khur reserved forest & -0.15 & 0.10 & 0.27 & 0.15 \\
\hline Chiltan reserved forest & -0.15 & 0.15 & 0.25 & 0.14 \\
\hline Hazar Ganji reserved forest & -0.06 & 0.13 & 0.26 & 0.00 \\
\hline Hazar Ganji Chiltan national park & -0.22 & 0.05 & 0.23 & -0.09 \\
\hline
\end{tabular}


radiation for some sites as compared to its normal rise with the local seasonal change in weather during a year. However, comparative to regular and smooth surface terrain, the satellite data can fluctuate by $10-50 \mathrm{~W} \mathrm{~m}^{2}$, while the anomalies can arise up to $600 \mathrm{~W} / \mathrm{m}^{2}$ for its solar flux values over irregular terrain (Liou et al. 2007).

Relatively high correlation was found between standard data (CM SAF) and the base site, and Char Shakh study sites, given in Table 5. The study sites Hazar Ganji-Chiltan national park, Khur, Chiltan, and Hazar Ganji reserved forests show a negative correlation. At Tor Shor reserved forest, negative values of correlation coefficient were obtained for months; January -0.23 , April -0.35 , and May -0.26 . However, relatively agreeable correlation was found for other months of the year.

For study year, 2016 (till April), similarly agreeable trend of error statistics was found, shown in Table 6. Following the same trend, relatively low RMSE values were obtained for the base site and Char Shakh, while nearly similar values were observed for Tor Shor and Chiltan reserved forest. However, high values of RMSE (7-3.5) were obtained for Hazar Ganji-Chiltan national park, Hazar Ganji, and Khur reserved forests. Relatively low-to-moderate correlation was observed for the base site and Tor Shor reserved forest (Table 6).

\section{Conclusions}

The present study proposed the estimation of downward shortwave radiation (DSR) over the selected sites located at contrasting elevations over specified mountainous terrain of Quetta city using mountain microclimate extrapolator (MTCLIM-XL) with the integrative approach of remote sensing and geographic information system. To complement proposed approach, Hillshade analysis is applied with interpolation for assessment of DSR spatial distribution and variation over study sites and area. The findings demonstrate that the MTCLIM-XL extrapolate agreeable data values of daily shortwave radiation over complex terrain. Variations in findings of DSR values were observed for sites at high elevations due to a basic drawback of MTCLIM with limited consideration of influencing topographic factors relative to differential elevation gradients. Comparative analysis with EUMETSAT CMSAF data for sites; Hazar Ganji-Chiltan national park, Tor Shor, Khur, and Hazar Ganji reserved forest sites showed slightly high with values of errors during initial months' findings of the study year. Additional evaluation of the SZA inverse relation with DSR showed contrasting trend due to fluctuations in values of DSR with respect to local seasonal change. However, the present approach explores the DSR potential sites and area surfaces on basis of spatial distribution. Sites with high elevation depict high potential of above the threshold level of $250 \mathrm{~W} / \mathrm{m}^{2}\left(2 \mathrm{~kW} \mathrm{~h} / \mathrm{m}^{2} /\right.$ day $)$ with 'maximum sun view' over the surfaces. The present study approach will be applicable to complement the climatological and hydrological studies over complex terrains. We anticipate that complemented with interpolation approach and quantification of Hillshade analysis, the present study will be useful for researchers and policymakers on basis of real-time estimation of downward shortwave radiation estimation for exploration of potentialbased sparsely located sites on areas with irregular terrain and no ground data, both on a local and regional scale.

Acknowledgments This study was supported/funded by the Chinese Scholarship Council (CSC). We are thankful to William Matthew Jolly (US Forest Service) NSDC for the open provision of MTCLIM$\mathrm{XL}$. For the electronic data provision for present study findings validation as well as for throughout timely response and guidance, we are grateful to EU METSAT CMSAF Operation Team ("Deutscher Wetterdienst", Offenbach, Germany).

Open Access This article is distributed under the terms of the Creative Commons Attribution 4.0 International License (http://creative commons.org/licenses/by/4.0/), which permits unrestricted use, distribution, and reproduction in any medium, provided you give appropriate credit to the original author(s) and the source, provide a link to the Creative Commons license, and indicate if changes were made.

\section{References}

AccuWeather $^{\circledR}$ (2016) Min, Max temperature, precipitation for Quetta, Pakistan. AccuWeather, Inc ${ }^{\circledR}$. http://www.accuweather. com/en/pk/pakistan-weather. Accessed April 2016

Ahmed K, Shahid S, Harun SB (2014) Spatial interpolation of climatic variables in a predominantly arid region with complex topography. Environ Syst Decis. doi:10.1007/s10669-0149519-0

Almeida AC, Landsberg JJ (2003) Evaluating methods of estimating global radiation and vapor pressure deficit using a dense network of automatic weather stations in coastal Brazil. Agric For Meteorol 118(3-4):237-250

Ambreen R, Qiu X, Ahmad IJ (2011) J Mt Sci 8:427. doi:10.1007/ s11629-011-2004-Z

AWG, Radiation Budget Application Team Version. (25 July 30, 2012) GOES-R advanced baseline imager (ABI) algorithm theoretical basis document for downward shortwave radiation (surface), and reflected shortwave radiation (TOA). NOAA, NESDIS, Center for Satellite Applications and Research

Bristow KL, Campbell GS (1984) On the relationship between incoming solar radiation and daily maximum and minimum temperature. Agric For Meteorol 31:159-166

Chiesi M, Maselli F, Bindi M et al (2002) Calibration and application of FOREST-BGC in a Mediterranean area by the use of conventional and remote sensing data. Ecol Model 154(3):251-262

Conzelmann C, Romañach SS (2010) Visualizing NetCDF files by using the EverVIEW data viewer. U.S. Geological Survey Fact Sheet 2010-3046

Custer SG, Farnes P, Wilson JP, Snyder RD (1996) A comparison of hand and spline-drawn precipitation maps for mountainous Montana. Water Resour Bull 32(2):393-405 
Daly C, Halblei M, Smith JI, Gibson WP et al (2008) Physiographically sensitive mapping of temperature and precipitation across the conterminous United States. Int J Climatol 28:2031-2064

Dozier J, Bruno J, Downey P (1981) A faster solution to the horizon problem. Comput Geosci 7:145-151

Glassy JM, Running SW (1994) Validating diurnal climatology logic of the MT-CLIM model across a climatic gradient in Oregon. Ecol Appl 4(2):248-257

Grafius DR, Malanson GP (2009) Precipitation and temperature estimation error at alpine treeline ecotones using the mountain climate simulator model (MT-CLIM). Phys Geogr 30(4):285-307. doi:10.2747/0272-3646.30.4.285

Hamann A, Wang TL (2005) Models of climatic normals for genecology and climate change studies in British Columbia. Agric For Meteorol 128(3-4):211-221

Hungerford RD, Running SW, Nemani RR, Coughlan JC (1989) MTCLIM: a mountain microclimate extrapolation model. USDA Forest Service, Res.Paper INT-414

Hunter RD, Meentemeyer RK (2005) Climatologically aided mapping of daily precipitation and temperature. J Appl Meteorol 44(10):1501-1510

Jeffrey SJ, Carter JO, Moodie KB, Beswick AR (2001) Using spatial interpolation to construct a comprehensive archive of Australian climate data. Environ Model Softw 16:309-330

Juanma S, Carmen Sánchez de Cos M, Jiménez C (2006) Comparison of ground based global radiation measurements from AEMET radiation network with SIS (surface incoming shortwave radiation) from Climate Monitoring-SAF: AEMET, Spanish State Meteorological Agency Demóstenes 4, Málaga, Spain

Klassen S, Bugbee B (2004) Shortwave radiation: Crop Physiology Laboratory Department of Plants, Soils, and Biometeorology. Utah State University, pp 43

Liou KN, Lee W-L, Hall A (2007) Radiative transfer in mountains: application to the Tibetan Plateau. Geophys Res Lett 34:L23809. doi:10.1029/2007GL031762

Lo YH, Blanco JA, Seely B, Welham C, Kimmins JP (2011) Generating reliable meteorological data in mountainous areas with scarce presence of weather records: the performance of MTCLIM in interior British Columbia, Canada. Environ Model Softw. doi:10.1016/j.envsoft.2010.11.005

McKeeny DW, Pedlar JH, Papadopol P, Hutchinson MF (2006) The development of 1901-2000 historical monthly climate models for Canada and the United States. Agric For Meteorol 138(1-4):69-81

Open Topography (2016) High-resolution shuttle radar topography mission (SRTM GL1). Global 30 m DEM for Quetta, Pakistan. Open Topography. http://www.opentopography.org/. Accessed 10 Apr 2016. doi:10.5067/MEaSUREs/SRTM/SRTMGL1.003

Running SW, Nemani RR, Hungerford RD (1987) Extrapolation of synoptic meteorological data in mountainous terrain and its use for simulating forest evapotranspiration and photosynthesis. Can J For Res 17(6):472-483

Schulz J, Thomas W, Müller R, et al (2008) Operational climate monitoring from space: the EUMETSAT satellite application facility on climate monitoring (CM-SAF). Atmos Chem Phys Discuss 8:8517-8563. SRef-ID: 1680-7375/acpd/2008-8-8517, accepted for publication in Atmos Chem Phys

Sultan S, Wu RG, Ahmad I, Ahmad MF (2014) Modeling of diffuse solar radiation and impact of complex terrain over Pakistan using RS/GIS. J Geogr Inf Syst. doi:10.4236/jgis.2014.64035

Sultan S, Lin H, Wu R, Ahmad FM, Iftikhar A (2015) Impact of slope, aspect and cloud cover on the distribution of incoming global solar radiation over Pakistan. In 23rd international conference on geoinformatics, Wuhan, pp 1-11. doi: 10.1109/ GEOINFORMATICS.2015.7378566

Thornton PE, Running SW, White MA (1997) Generating surfaces of daily meteorological variables over large regions of complex terrain. J Hydrol 190:214-251. doi:10.1016/S0022-1694(96)03128-9

Thornton PE, Hasenauer H, White MA (2000) Simultaneous estimation of daily solar radiation and humidity from observed temperature and precipitation: an application over complex terrain in Austria. Agric For Meteorol 104(4):255-271

Trentmann J, Müller R (2013) Validation report MSG surface radiation edition 1, EUMETSAT satellite application facility on climate monitoring. doi:10.5676/EUMETSAT_SAF_CM/ CLAAS/V001

Wikipedia N p (2016) Quetta 12/06/2016. Accessed 12 June 2016

$\mathrm{Yu}$ J-Y The atmosphere, solar radiation and seasons [lecture notes].Retrieved from http://www.ess.uci.edu/ yu/class/ess5/ Chapter.2.solar_radiation_season.all.pdf

Yang KRT, Pinker Y, Ma T, Koike MM, Wonsick SJ, Cox Y, Zhang P, Stackhouse P (2008) Evaluation of satellite estimates of downward shortwave radiation over the Tibetan Plateau. J Geophys Res 113:D17204. doi:10.1029/2007JD009736 